\title{
ANALISIS PENGARUH IMPLEMENTASI ERP TERHADAP PROFITABILITAS DAN NILAI PERUSAHAAN
}

\author{
Sri Ayu Pracita \\ ayu.prachita@gmail.com \\ UniversitasAirlangga, Surabaya \\ Noorlaily Soewarno \\ noorlailie-s@feb.unair.ac.id \\ UniversitasAirlangga, Surabaya \\ Isnalita \\ isnalitas@feb.unair.ac.id \\ Universitas Airlangga, Surabaya
}

\begin{abstract}
This study aims to test empirically the effect of ERP implementation on profitability and corporate value. This analysis uses independent variable that is profitability and company value, and the dependent variable is ERP implementation. The sample used in this research is a manufacturing company listed on Indonesia Stock Exchange which has implemented ERP. Data collection is done by looking at the financial statements and annual report of manufacturing companies from 2010 to 2016. Research method using multiple regression method with panel data. The results of this study prove that the implementation of ERP has a significant positive effect on profitability by using Net Profit Margin, and ERP implementation also significantly influence the value of the company by using the value of the stock market. The conclusion of this research is that companies that have implemented ERP can have better performance than before implementing ERP.
\end{abstract}

Keywords: ERP Implementation, Profitability, Corporate Value

\section{PENDAHULUAN}

Di era ekonomi global saat ini yang sangat kompetitif dan cepat berubah, perusahaan dituntut untuk menggunakan teknologi informasi untuk mendukung kinerja proses bisnisnya. Manajemen teknologi informasi membutuhkan visi strategi yang dapat menyatukan antara teknologi informasi dan proses bisnis. Strategi teknologi yang mengacu pada investasi spesifik dalam bentuk perbedaan jenis sistem, seperti sistem ERP (Enterprise Resource Planning). ERP (Enterprise Resource Planning) ialah struktur sistem informasi yang dapat mengintegrasikan fungsi pemasaran, fungsi produksi, fungsi logistik, fungsi keuangan, fungsi sumber daya, dan fungsi lainnya (Wicaksono, Mulyo dan Rianto.2015). ERP saatinitelah berkembang sebagai alat integrasi yang memiliki tujuan untuk mengintegrasikan semua aplikasi perusahaan ke pusat penyimpanan data sehingga dengan mudah dapatdiakses oleh semua bagian yang membutuhkan, termasuk mengintegrasikan hubungan perusahaan dengan pemasok. Dan software ERP yang banyak digunakan olehperusahaan saatiniyaitu SAP dan ORACLE. 
Penerapan implementasi ERP sendiri sangat rumit karena biaya yang dibutuhkan sangat besar dan dalamkurun waktu yang tidak sebentar (Rahmawati,2008). Kegagalan sistem ERP dapat terjadi dikarenakan kompleksitas ketika implementasi, adanya masalah integrasi, kekurangan dana, ketidaksesuaian penjadwalan proyek, dan resistensi pengguna terhadap perubahan. Pada umumnya penerapan implementasi ERP membutuhkan presentase biaya sekitar $0,82 \%$ dari pendapatan perusahaan sedangkan pada perusahaan kecil dapat mencapai $13,65 \%$ dari pendapatannya yang dinyatakan oleh (Mabert et, al. 2000). Di Indonesia sendiri terdapat banyak kasus dimana implementasi ERP memakan waktu jauh lebih lama dari praktik umumnya yang hanya memerlukan waktu 6 hingga 12 bulan, namun banyak juga perusahaan yang secara umum dapat dikatakan berhasil, sehingga perusahaan mampu meningkatkan kepatuhan dan tata kelola (Good Corporate Governance) dan meningkatkan citra perusahaan.

Dalam kurun waktu 3 tahun untuk pengimplementasian ERP tidak berpengaruh terhadap residual income perusahaan, rasio penjualan atas penghasilan dan biaya umum serta administrasi, namun adanya perbaikan yang signifikan dalam kinerja perusahaan yang dihasilkan dari penurunan jatah harga pokok penjualan (Poston dan Severin,2001). Implementasi teknologi ERP memberikan peningkatan innovation performance dan quality performance yang berdampak secara langsung pada peningkatan kinerja perusahaan khususnya dalam peningkatan akurasi informasi antar departemen diperusahaan, respon terhadap pelanggan yang lebih cepat, pengambilan keputusan yang lebih tepat dan penggunaan sumber daya yang lebih baik dan akhirnya mampu meningkatkan pendapatan perusahaan. Hal ini telah dibuktikan oleh peneliti Dityawarman et,al (2016); Tarigan (2004).

Peningkatan dalam kinerja perusahaan berkaitan erat dengan nilai perusahaan, nilai perusahaan merupakan nilai pasar saham yang mencerminkan kekayaan pemilik. Semakin tinggi harga saham diperdagangkan semakin tinggi arti kekayaan pemilik, begitu pula sebaliknya. Faktor-faktor yang dianalisa oleh para pemaham dan pemerhati pasar modal yakni Return on Aset (ROA), Return on Equity (ROE), Debt to Earning Ratio (DER), Growth,Earning (EPS), Price Earning Ratio (PER), Firm Size, Price Book Value (PBV), Laverage, Dividend Yield Ratio, Investment Opportunity Set (IOS), Corporate Governance. MenurutWelley dan Victoria (2015) dan Budi dan Eka (2014)secara terus menerus profitabilitas, ukuran perusahaan dan keputusan investasi sangat berpengaruh terhadap nilai perusahaan.

Profitabilitas suatu perusahaan memiliki pengaruh yang tinggi terhadap nilai perusahaan. Semakin tinggi profit yang didapat perusahaan maka menunjukkan kemampuan maksimal dalam mengelola aset keseluruhan. Penelitian ini menggunakan variabel kontrol ukuran perusahaan dan juga keputusan investasi. Ukuran perusahaan dilihat dari besar kecilnya total aktiva. Semakin besar total aktiva maka menunjukkan semakin banyak aset yang dimiliki yang berdampak pada nilai perusahaan. Keputusan investasi merupakan kebijakan manajemen dalam memperoleh laba besar dengan risiko yang dapat dikelola dengan tujuan mengoptimalkan nilai perusahaan.

Secara deskriptif tujuan dalam penelitian ini yaitu untuk mengetahui apakah terdapat pengaruh implementasi ERP terhadap profitabilitas dan juga nilai perusahaan. Karena profitabilitas suatu perusahaan memiliki pengaruh yang tinggi terhadap nilai perusahaan sehingga apakah dengan implementasi ERP, terdapat adanya pengaruh pada profitabilitas dan juga nilai perusahaan. Permasalahan yang penulis teliti saat ini semua perusahaan rata-rata telah menggunakan teknologi informasi yang dapat membantu mendukung proses bisnisnya, dan banyak perusahaan yang sudah mulai menggunakaan 
salah satu teknologi informasi yang canggih yaitu ERP. Namun masih ada juga yang belum menerapkannya dikarenakan biaya yang cukup besar dan juga yang menggunakannya biasa termasuk perusahaan yang besar, dengan pengimplementasian ERP ini apakah dapat meningkatkan kinerja suatu perusahaan dengan melihat pengaruhnya terhadap profitabilitas dan juga nilai perusahaan.

Oleh karena itu menjadi sangat penting untuk melakukan penelitian untuk membuktikan prrofitabilitas dan nilai perusahaan berpengaruh terhadap implementasi ERP. Perbedaan penelitian ini dengan peneliti terdahulu yakni terdapat dalam analisa pengaruh kinerja perusahaan terhadap nilai perusahaan, apakah mampu memperkuat atau memperlemah hubungan kinerja perusahaan terhadap nilai perusahaan.

\section{LANDASAN TEORI DAN PENGEMBANGAN HIPOTESIS \\ 2.1 Pengertian ERP}

ERP merupakan singkatan dari tiga elemen kata Enterprise (Perusahaan/Organisasi), Resources (Sumber Daya), Planning (Perencanaan). Tiga kata tersebut mencerminkan sebuah konsep yang berujung pada kata kerja yaitu planning, dengan demikian ERP menekankan pada aspek perencanaan (Wijaya dan Suparto,2009). Jadi ERP merupakan suatu konsep untuk merencanakan dan mengelola sumber daya perusahaan, yaitu berupa paket aplikasi yang terintegrasi dan multi modul yang dirancang untuk melayani dan mendukung berbagai fungsi dalam perusahaan.

\subsection{Pengertian Sistem ERP}

Sistem ERP ialah paket peranti lunak bermodul yang berevolusi dari sistem perencanaan sumber daya perusahaan traditional (Manufacturing Resources PlanningMRP II). Istilah ERP dibuat oleh Gatner Group dan telah secara luas digunakan dalam beberapa tahun belakangan ini. Dalam model tradisional, setiap area fungsional atau departemen memiliki sistemn komputer yang dioptimalkan sesuai dengan cara perusahaan dalam menjalankan bisnis rutinnya. Perusahaan juga biasanya memiliki model tradisional arsitektur basis data tertutup yang didalamnya terdapat basis data yang berbeda, terpisah, dan juga independen. Sehingga kurangnya komunikasi yang efektif antar berbagai sistem seringkali menjadi akibat dari proses desain sistem yang terpisahpisah (Hall, 2007).

ERP sendiri menggabungkan semua hal ke dalam sebuah sistem terintegrasi yang mengakses sebuah basis data untuk memfasilitasi berbagai informasi dan memperbaiki komunikasi diperusahaan. Sistem ERP mendukung arus informasi yang lancar dan tampak diperusahaan yaitu dengan menjembatani komunikasi antara supplier dan konsumen (Wijaya dan Suparto,2009). Data dalam basis operasional ERP dibuat dengan model yang tetap independen dari apliksi manapun. Pengguna data bersama diantara para pengguna terjadi melalui tampilan sesuai dengan aplikasi yang menyajikan data dalam cara yang mana dapat memenuhi kebutuhan semua pengguna.

\subsection{Pengembangan Hipotesis}

Forslund (2010) mengatakan bahwa adanya kemampuan sistem ERP dalam membantu dan mengevaluasi pengelolaan kinerja supply chain. Melalui studi empiris, berdasarkan kerangka dengan mewawancarai responden selama 12 tahun di pasar Swedia akhirnya menyimpulkan bahwa perlu adanya pengembangan kerangka kerja untuk permintaan pengadaan dari rantai pasokan supply chain. Adapun sistem yang mendukung kemampuan rantai pasokan yang baik untuk pengelolaan kinerja supply chain adalah Oracle. Dengan meningkatnya kinerja hal ini akan meningkatkan pendapatan dan menjadi acuan bagi perusahaan untuk meningkatkan nilai perusahaan. Hal ini dibuktikan kembali 
oleh Wicaksono et,al (2015) dalam penelitiannya yang menyatakan bahwa penerapan sistem ERP memiliki dampak positif terhadap komponen kinerja pengguna.

Dalam penelitiannya Hunton (2002) menyatakan bahwa Return on Asset (ROA), Return on Investment (ROI), dan Asset Turnover (ATO) secara signifikan lebih baik selama periode 3 tahun awal adopsi, dibandingkan dengan non adopters ERP. Sebaliknya perbedaan yang signifikan yakni kinerja keuangan non adopters menurun dari waktu ke waktu dibandingkan dengan yang mengadopsi ERP. Hunton juga melaporkan bahwa adanya interaksi yang signifikan antara ukuran perusahaan dan kesehatan keuangan sehubungan dengan ROA, ROI, dan ROS (Hunton, 2002). Berdasarkan penelitian yang dilakukan oleh Forslund (2010) dan Wicaksono et, al(2015) yang menyatakan bahwa implementasi ERP meningkatkan kinerja perusahaan, maka hipotesis yang dalam penelitian ini ialah :

H1 : Implementasi ERP memiliki pengaruh positif terhadap profitabilitas

Davenport (1998) menyatakan bahwa sistem ERP yang terintegrasi memungkinkan untuk manager berbagi informasi, dan informasi tersbeut dapat digunakan untuk mengawasi kinerja perusahaan. Sistem yang terintegrasi dapat mengeliminasi rintangan diantara berbagai fungsi yang ada di dalam suatu perusahaan, sehinga memungkinkan manager untuk mendapatkan informasi akuntansi yang dapat diandalkan. Laporan keuangan merupakan salah satu jantung dari sebuah perusahaan, untuk dapat memproyeksikan masa depan juga alat untuk pengambilan keputusan bagi pengguna baik itu pihak dalam maupun pihak luar.

Namun berbeda halnya dengan penelitian Sehwan et,al (2016) dan Morris (2011) yang membahas tentang dampa dari implementasi ERP terhadap kinerja perusahaan. Penelitian Sehwan et,al (2016) dengan sampel perusahaan Korea yang mengadopsi ERP pada akhir tahun 2000-an. Penelitian ini membandingkan kinerja keuangan perusahaan yang mengadopsi ERP dan non-adopsi setelah memisahkan periode sebelum dan sesudah adopsi ERP. Sehwan et, al (2016) menyatakan bahwa mereka tidak menemukan hubungan yang positif dan signifikan antara perusahaan yang mengadopsi ERP terhadap kinerja perusahaan dalam rasio laba. Hasil ini dapat menunjukkan bahwa penelitian ini bertentangan dengan era sistem informasi dan standar informasi saat ini yang tidak memiliki keunggulan kompetitif lebih atas pesaing.

Sedangkan hasil penelitian Morris (2011) menyatakan bahwa walupun nilai bisnis dari implementasi ERP telah banyak diperdebatkan pada aspek perdagangan baik dalam bentuk kualitatif ataupun studi kasus, ada beberapa bukti statistik sampel apakah manfaat dari implementasi ERP melebihi biaya dan risiko. Dengan multi year perusahaan yang mengimplementasikan ERP dan juga data keuangan, penelitian ini menemukan bahwa adanya perlambatan dalam kinerja bisnis dan produktivitas tak lama setelah implementasi ERP, meskipun pada akhirnya perusahaan yang berinvestasi pada ERP cenderung menunjukkan kinerja yang lebih tinggi di berbagai metrik keuangan. Berdasarkan penelitian yang berkenaan dengan implementasi ERP maka hipotesis yang diajukan adalah :

$\mathbf{H}_{2}$ : Implementasi ERP memiliki pengaruh positif terhadap nilai perusahaan

\section{METODOLOGI PENELITIAN}

Jenis penelitian yang digunakan dalam penelitian ini ialah penelitian kuantitatif dengan statistik inferensial. Jenis data yang digunakan dalam penelitian ini ialahdata sekunder yang diperoleh dari perusahaanmanufaktur yang terdaftar di Bursa Efek Indonesia (BEI). Data yang digunakan ialah laporan keuangan dan laporan tahunan 
perusahaan untuk periode sesudah penerapan ERP. Periode annual report ini digunakan data tahun 2010 hingga 2016. Pembatasan penggunaan data beberapa periode akan memberikan penjelasan mengenai pengaruhnya implementasi ERP terhadap nilai

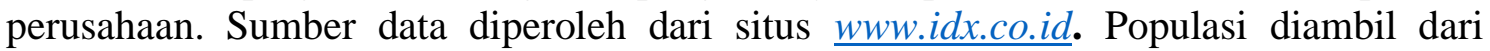
perusahaan yang telah menerapkan Enterprise Resources Planning(ERP) dan terdaftar di Bursa Efek Indonesia. Alasan pemilihan BEI dikarenakan investasi sangat berperan penting dalam menentukan kestabilan langkah suatu perusahaan, dan berhubungan erat terhadap perkembangan informasi yang akan berdampak pada performance perusahaan. Sehingga peneliti ingin meninjau sejauh mana dampak impementasi ERP atas hubungan kinerja terhadap nilai perusahaan.

Metode penelitian ini menggunakan metode purpose sampling yaitu sampel dipilih berdasarkan tujuan dan kriteria. Dari ujumlah populasi tersebut selanjutnya dilakukan proses seleksi terhadap perusahaan-perusahaan berdasarkan kriteria yang sesuai dengan penelitian yaitu :

a. Perusahaan manufakturyang telah mengimplementasi ERP dilaporan tahunan

b. Perusahaan manufaktur yang sahamnya terdaftar pada Bursa Efek Indonesia secara berturut-turut dari periode 2010-2016

c. Perusahaan manufaktur yang menerbitkan laporan keuangan secara terbuka (publik) per 31 desember berturut-turut selama periode 2010-2016 dan mengungkapkan informasi keuangan melalui website. Hal ini dilakukan untuk menghindari adanya waktu parsial dalam pengukuran variabel.

Penelitian ini menggunakan variabel bebas yaitu: profitabilitas dan nilai perusahaan serta satu variabel terikat yaitu: implementasi ERP. Masing-masing definisi operasional variabel penelitian di jelaskan pada tabel 1 :

Tabel 1. Definisi Operasional Variabel

\begin{tabular}{|c|c|c|c|}
\hline Nama Variabel & Indikator & Rumus & Skala \\
\hline $\begin{array}{l}\text { Dependen : } \\
\text { Implementasi } \\
\text { ERP }\end{array}$ & $\begin{array}{l}\text { Dummy tahun } \\
\text { implementasi } \\
\text { ERP }\end{array}$ & $\begin{array}{l}\text { "1" untuk perusahaan } \\
\text { yang telah menerapkan } \\
\text { ERP setelah } 3 \text { tahun, dan } \\
\text { "0" jika tidak } \\
\text { menerapkan ERP }\end{array}$ & Ordinal \\
\hline $\begin{array}{l}\text { Independen : } \\
\text { Profitabilitas : } \\
\text { Net Profit } \\
\text { Margin (NPM) }\end{array}$ & $\begin{array}{l}\text { Hasil bersih dari } \\
\text { serangkaian } \\
\text { kebijakan }\end{array}$ & $\begin{array}{l}N P M \\
=\frac{\text { Laba setelah pajak }}{\text { penjualan bersih }}\end{array}$ & Rasio \\
\hline $\begin{array}{l}\text { Nilai Perusahaan } \\
: \\
\text { Harga Pasar } \\
\text { Ekuitas (MVE) }\end{array}$ & $\begin{array}{l}\text { Harga pasar } \\
\text { ekuitas yang } \\
\text { melaporkan nilai }\end{array}$ & $\begin{array}{l}\text { MVE = } \\
\text { Harga Penutupan saham } \\
\times \sum \text { saham beredar }\end{array}$ & Rasio \\
\hline
\end{tabular}

Sumber : Hasil Pengolahan Data, 2017

Untuk menguji hipotesis digunakan model persamaan regresi berganda sebagai berikut :

\section{Persamaan I}

$\mathrm{DP}_{\mathrm{it}}=\beta_{0}+\beta_{1} \mathrm{NPM}_{\mathrm{it}}+\varepsilon_{\mathrm{it}}$

Persamaan II

$\mathrm{DP}_{\mathrm{it}}=\beta_{0}+\beta_{1} \mathrm{NPM}_{\mathrm{it}}+\beta_{2} \mathrm{MVE}_{\mathrm{it}}+\varepsilon_{\mathrm{it}}$

Keterangan : 


$\begin{array}{ll}\text { MVE } & \text { : Harga pasat ekuitas yang melaporkan nilai } \\ \text { NPM } & \text { : Laba setelah pajak dibagi dengan total aktiva perusahaan } \\ \text { DP } & \text { : Dummy ERP } \\ \text { i } & \text { : Perusahaan } \\ \text { t } & \text { : Waktu }\end{array}$

Persamaan I digunakan untuk mengetahui dampak implementasi ERP terhadap kinerja yang diukur melalui profitabilitas perusahaan. Beberapa variabel ditranformasikan ke bentuk logaritma untuk menghindari ketimpangan di antara perusahaan dan guna menyederhanakan angka. Sedangkan persamaan II digunakan untuk mengetahui hubungan variabel independen seperti NPM dan MVE terhadap variabel dependen yakni implementasi ERP (DP)secara individual dan secara keseluruhan.

Penelitian ini menggunakan metode regresi data panel untuk menganalisis variabel-variabel yang saling mempengaruhi. Tujuannya agar hasil estimasi yang diperoleh jauh lebih baik, yaitu dengan adanya peningkatan jumlah observasi yang berimplikasi pada derajat kebebasan. Agar dapat diolah data panel ini memiliki kriteria yang disebut cross section. Kemudian periode yang digunakan dalam penelitian ini berjumlah sepuluh tahun yang disebut time series dengan jumlah variabel dependen dan independen ada tiga variabel yaitu profitabilitas, nilai perusahaan dan dummy ERP.

\section{HASIL DAN PEMBAHASAN}

\subsection{Hasil Penelitian}

Perusahaan yang diteliti dalam penelitian ini adalah perusahaan manufaktur yang listed di Bursa Efek Indonesia (BEI) dan menerapkan ERP, yang berjumlah 44 perusahaan dengan periode waktu penelitian tahun 2010 hingga 2016. Perusahaan yang menjadi sampel penelitian telah terpilih berdasarkan ketentuan tertentu yang telah ditetapkan oleh peneliti. Data perusahaan yang diteliti secara lengkap dapat dilihat pada lampiran 1. Dan berikut tabel yang menjelaskan jumlah perusahaan yang diteliti sesuai dengan teknik sampling yang dijelaskan di metedologi penelitian.

Tabel 2. Jumlah Perusahaan yang Diteliti

\begin{tabular}{|c|l|c|}
\hline No & \multicolumn{1}{|c|}{ Keterangan } & Jumlah \\
\hline 1. & $\begin{array}{l}\text { Perusahaan manufaktur yang menerapkan ERP dan } \\
\text { terdaftar di BEI selama 2010-2016 }\end{array}$ & 45 \\
\hline 2. & Laporan keuangan yang tidak ada dan tidak lengkap & $(1)$ \\
\hline 3. & Jumlah sampel secara keseluruhan & 44 \\
\hline
\end{tabular}

Sumber : Hasil Pengolahan Data, 2017

\section{a) Statistik Deskriptif}

Dalam penelitian ini meneliti tentang dampak implementasi ERP terhadap profitabilitas dan nilai perusahaan. Adapun implementasi ERP diukur menggunakan dummy dengan ketentuan " 1 = jika menerapkan ERP" dan " $0=$ jika tidak menerapkan ERP”. Dan untuk profitabilitas perusahaan dijelaskan melalui variabel Net Profit Margin (NPM), dan nilai perusahan dijelaskan melalui harga pasar ekuitas (MVE).

Variabel-variabel yang digunakan dalam penelitian ini dapat diperoleh melalui laporan tahunan dan laporan keuangan perusahaan manufaktur pada tahun 2010 hingga 2016. Dan pengujian statistik deskriptif masing-masing variabel penelitian dapat dilihat melalui tabel di bawah ini. 
Tabel 3. Statistik Deskriptif

Descriptive Statistics

\begin{tabular}{|l|r|r|r|r|r|}
\hline & N & Minimum & $\begin{array}{c}\text { Maximu } \\
\mathrm{m}\end{array}$ & Mean & $\begin{array}{c}\text { Std. } \\
\text { Deviation }\end{array}$ \\
\hline DP & 308 &, 00 & 1,00 &, 8409 &, 36636 \\
NPM & 308 & 58,00 & 9651,00 & 2073,8344 & 2042,36667 \\
LNMVE & 308 & 6,91 & 9,21 & 8,0666 &, 67965 \\
Valid N & 308 & & & & \\
(listwise) & & & & \\
\hline
\end{tabular}

Sumber : Hasil Pengolahan Data, 2017

Berdasarkan hasil tabel diatas, dapat dilihat bahwa data yang digunakan dalam penelitian ini sebanyak 308 data yang bersumber dari laporan tahunan dan laporan keuangan. Dengan perhitungan bahwa data yang digunakan ialah data hasil dari pemeriksaan selama 7 tahun (time series) dan pada masing-masing tahun ada 44 objek perusahaan (cross sections).

b) Pengujian Hipotesis

Pengujian hipotesis dalam penelitian ini menggunakan analisis regresi berganda. Berdasarkan hasil pengolahan data dengan SPSS, selanjutnya pengujian hipotesis secara statistik dilakukan dengan menggunakan uji $t$ dan uji F. Dan berikut tabel uji t untuk persamaan I :

\section{Tabel 4. Uji T Persamaan I}

Coefficients $^{\text {a }}$

\begin{tabular}{|c|c|c|c|c|c|}
\hline \multirow[t]{2}{*}{ Model } & \multicolumn{2}{|c|}{$\begin{array}{c}\text { Unstandardized } \\
\text { Coefficients }\end{array}$} & $\begin{array}{c}\text { Standardized } \\
\text { Coefficients }\end{array}$ & \multirow[t]{2}{*}{$\mathrm{t}$} & \multirow[t]{2}{*}{ Sig. } \\
\hline & B & Std. Error & Beta & & \\
\hline (Constant) & ,890 &, 030 & & 30,126 & ,000 \\
\hline NPM & $\begin{array}{r}-2,389 \mathrm{E}- \\
005\end{array}$ & ,000 &,- 133 & $-2,351$ & ,019 \\
\hline
\end{tabular}

a. Dependent Variable: DP

Sumber : Hasil Pengolahan Data, 2017

Persamaan I :DP it $=\beta_{0}+\beta_{1} \mathrm{NPM}_{\mathrm{it}}+\varepsilon_{\mathrm{it}}$

Berdasarkan hasil pengujian statistik t pada tabel 4 diatas, menunjukkan nilai Sig. Untuk variabel DP sebesar 0,019 $(\mathrm{p}<0,05)$ sehingga hipotesis diterima yang artinya implementasi ERP(DP)berpengaruh signifikan secara parsialterhadap profitabilitas (NPM). Selanjutnya untuk uji t persamaan II disajikan dalam tabel 5.

\section{Tabel 5. Uji T Persamaan II}

ANOVA $^{\mathrm{a}}$

\begin{tabular}{|c|c|c|c|c|c|c|}
\hline \multicolumn{2}{|c|}{ Model } & $\begin{array}{l}\text { Sum of } \\
\text { Squares }\end{array}$ & $\mathrm{Df}$ & $\begin{array}{c}\text { Mean } \\
\text { Square }\end{array}$ & $\mathrm{F}$ & Sig. \\
\hline \multirow{3}{*}{1} & Regression &, 804 & 2 & \multirow{3}{*}{$\begin{array}{l}, 402 \\
, 132\end{array}$} & \multirow[t]{3}{*}{3,035} & \multirow[t]{3}{*}{, $050^{\mathrm{b}}$} \\
\hline & Residual & 40,400 & 305 & & & \\
\hline & Total & 41,205 & 307 & & & \\
\hline
\end{tabular}

a. Dependent Variable: DP 
b. Predictors: (Constant), LNMVE, NPM

Sumber : Hasil Pengolahan Data, 2017

Persamaan II : DP it $=\beta_{0}+\beta_{1} \mathrm{NPM}_{\mathrm{it}}+\beta_{2} \mathrm{MVE}_{\mathrm{it}}+\varepsilon_{\mathrm{it}}$

Berdasarkan hasil pengujian statistik t pada tabel 5 diatas, didapatkan nilai Sig. 0,050 ( $\mathrm{p}=0,05)$ maka dapat disimpulkan bahwa hipotesis diterima, artinya variabel $\mathrm{Net}$ Profit Margin (NPM) dan implementasi ERP (DP) berpengaruh signifikan secara parsial terhadap nilai perusahaan (MVE).

c) Uji Kelayakan Model

Analisis sebelumnya yaitu pada analisis t yang memfokuskan pengujian variabel bebas terhadap variabel terikat secara individual. Oleh karena itu, perlunya melakukan pengujian secara bersamaan untuk pengaruh dari semua variabel bebas terhadap variabel terikat dengan uji $\mathrm{F}$. Berikut tabel 6 uji $\mathrm{F}$ dengan persamaan : $\mathrm{DP}_{\mathrm{it}}=\beta_{0}+\beta_{1} \mathrm{NPM}_{\mathrm{it}}+$ $\beta_{2} \mathrm{MVE}_{\mathrm{it}}+\varepsilon_{\mathrm{it}}$

Tabel 6. Uji F

ANOVA $^{\mathrm{a}}$

\begin{tabular}{|c|c|c|c|c|c|c|}
\hline \multicolumn{2}{|c|}{ Model } & $\begin{array}{l}\text { Sum of } \\
\text { Squares }\end{array}$ & Df & $\begin{array}{c}\text { Mean } \\
\text { Square }\end{array}$ & $\mathrm{F}$ & Sig. \\
\hline \multirow{3}{*}{1} & Regression &, 804 & 2 & \multirow{3}{*}{$\begin{array}{l}, 402 \\
, 132\end{array}$} & \multirow[t]{3}{*}{3,035} & \multirow[t]{3}{*}{, $050^{\mathrm{b}}$} \\
\hline & Residual & 40,400 & 305 & & & \\
\hline & Total & 41,205 & 307 & & & \\
\hline
\end{tabular}

Sumber : Hasil Pengolahan Data, 2017

Secara simultan, Net Profit Margin (NPM), dan Implementasi ERP (MVE) berpengaruh signifikan terhadap variabel terikat implementasi ERP (DP). Hal ini disebabkan oleh nilai probabilitas menunjukkan nilai 0,050 yang mana sama dengan nilai taraf yaitu 0,05 . Dengan demikian keputusan yang diambil adalah terima $\mathrm{H}_{1}$ dan tolak $\mathrm{H}_{0}$, yang berarti model regresi penelitian ini signifikan. Maka model pada penelitian ini menunjukkan adanya pengaruh yang signifikan secara simultan.

Seberapa besar garis regresi menjelaskan sifat datanya atau seberapa persentase variabel bebas secara bersama-sama menjelaskan variabel terikat yang di tunjukkan oleh koefisien determinasinya. Sehingga secara keseluruhan variabel terikat (dependen) implementasi ERP (DP) dapat dijelaskan oleh variabel bebas yang terdiri dari : Net Profit Margin (NPM) dan harga pasar ekuitas (MVE) dengan nilai Adjusted R-Square sebesar 40,20\% dan 13,20\% sisanya dijelaskan oleh variabel di luar model ini. Besarnya nilai koefisien determinasi berkisar antara 0 (nol) sampai dengan 1 (satu). Hal ini menunjukkan bahwa semakin tinggi nilai Adjusted $R$-Square dan mendekati 1, maka semakin erat hubungan entara variabel bebas dengan variabel terikat.

\subsection{Pembahasan}

Seperti yang telah dibahas diatas mengenai hasil penelitian yang menyatakan bahwa variabel implementasi ERP (DP) dapat dijelaskan oleh variabel Net Profit Margin (NPM) dan harga pasar ekuitas (MVE).

\section{a) Analisis Pengaruh Implementasi ERP Terhadap Profitabilitas}

Pengujian terhadap variabel implementasi ERP memiliki pengaruh positif signifikan terhadap profitabilitas yang diukur oleh Net Profit Margin (NPM). Hasil penelitian ini sesuai dengan penelitian yang dilakukan oleh Forslund (2010) yang mengatakan bahwa adanya kemampuan sistem ERP dalam membantu dan mengevaluasi 
pengelolaan kinerja perusahaan, begitu juga dengan penelitian yang dilakukan oleh Wicaksono et, al (2015) dan Hunton (2003) yang menyatakan dalam penelitiannya bahwa investasi ERP berpengaruh positif terhadap kinerja perusahaan.

Secara umum sesuai hasil yang telah didapatkan, maka penerapan ERP memberikan dampak yang posiftif bagi kinerja pengguna karena mampu menghasilkan kualitas nilai yang lebih baik dalam satu periode. Serta dapat membantu dalam proses pengawasan pekerjaan yang telah dan belum selesai dengan lebih cepat melalui adanya sistem ERP tersebut. Selain itu, pekerjaan yang memiliki standar yang jelas dengan menggunakan sistem ERP, agar dapat meningkatkan tanggung jawab terkait standar pekerjaannya. Oleh karena itu, dengan adanya peningkatan pengaruh atas implementasi ERP terhadap efektivitas perusahaan, hal ini akan memberikan dampak terhadap profitabilitas yang akan diperoleh oleh perusahaan tersebut.

\section{b) Analisis Pengaruh Implementasi ERP Terhadap Nilai Perusahaan}

Hasil penelitian ini menunjukkan bahwa variabel implementasi ERP (DP) berpengaruh positif signifikan terhadap harga pasar ekuitas (MVE). Hal ini mengindikasikan bahwa variabel implementasi ERP (DP) dapat menjelaskan variabel harga pasar ekuitas (MVE) secara signifikan. Dengan perusahaan mengimplementasikan ERP dapat menandakan adanya indikasi perusahaanyang baik sehingga menjadi penyebab adanya peningkatan terhadap nilai perusahan.

Dalam penelitian Forslund (2010); Wicaksono et, al (2015) dan Hunton (2003) menyatakan bahwa implementasi ERP berpengaruh terhadap kinerja perusahaan. Pada hipotesis satu telah ditemukan bukti adanya pengaruh positif antara implementasi ERP terhadap porfitabilitas. Dan untuk pengujian implementasi ERP terhadap nilai perusahaan memiliki pengaruh signifikan negatif, hal ini dikarenakan nilai dari signifikansinya sama dengan taraf penentuannya dan juga dikarenakan tahun untuk sampel yang digunakan dalam penelitian ini masih belum dapat mewakili dampak implementasi ERP terhadap nilai perusahaan secara menyeluruh. Sehingga kondisi ini menyebabkan implementasi ERP berpengaruh signifikan negatif terhadap variabel harga pasar ekuitas (MVE).

Implementasi ERP membutuhkan dana yang cukup besar, untuk pembiayaan pos seperti biaya pelatihan yang sering tidak diperkirakan sebelumnya di dalam pelaksanaannya. Biaya untuk integrasi dan uji coba antara aplikasi ERP dengan aplikasi lain dalam perusahaan yang dibangun dengan solusi kasus per kasus akan menimbulkan biaya yang tidak terlihat atau tidak disadari. Dan biaya untuk kustomisasi dan konversi data, selama proses implementasi semua data lama harus dimigrasi ke sistem ERP sehingga membutuhkan waktu yang cukup lama. Biaya untuk analisis data sebagai perbandingan data eksternal dari sistem lain. Semua biaya-biaya tersebut akan memiliki pengaruh terhadap laba yang akan diperoleh perusahaan. Namun dalam implementasi ERP itu sendiri dapat dikatakan bahwa imlementasi ERP dengan biaya yang terbilang tinggi akan memiliki return yang sebanding juga nantinya. Return tinggi yang didapatkan ini akan terlihat pengaruhnya setelah beberapa tahun setelah pengimplementasia ERP. Bahkan sebelum mendapatkan return tersebut terkadang perusahaan mengalami perlambatan laba terlebih dahulu sehingga berdampak pada nilai perusahaan.

\section{KESIMPULAN,KETERBATASAN DAN SARAN 5.1 Kesimpulan}

Hasil pengujian dalam penelitian ini yang menggunakan analisis regresi data panel dengan dua variabel bebas (independen) yaitu Net Profit Margin (NPM) dan harga pasar ekuitas (MVE) dan satu variabel terikat (dependen) yaitu implementasi ERP (DP). 
Sampel perusahaan yang digunakan sebanyak 44 perusahaan dengan periode 7 tahun dari 2010 hingga 2016, penelitian ini menggunakan Fix Effect Model untuk menganalisa pengaruh variabel dependen terhadap variabel independen.

Hasil dari penelitian ini menyatakan bahwa implementasi ERP berpengaruh positif signifikan terhadap profitabilitas yang diukur dengan variabel Net Profit Margin (NPM). Sehingga dapat disimpulkan bahwa hipotesis pertama yang menyatakan bahwa implementasi ERP berpengaruh positif signifikan terhadap profitabilitas dapat diterima.Dan hasil untuk implementasi ERP berpengaruh positif terhadap nilai perusahaan menunjukkan hubungan negatif dan signifikan yang akhirnya menurunkan nilai perusahaan. Hal ini dikarenakan tahun dari sampel yang digunakan masih terlalu kurang untuk digunakan dalam penelitian ini sehingga belum mewakili dampak implementasi ERP terhadap nilai perusahaan secara menyeluruh. Sehingga dapat disimpulkan bahwa hipotesis kedua yang menyatakan bahwa implementasi ERP berpengaruh signifikan terhadap nilai perusahaan dapat diterima.

\subsection{Keterbatasan}

Keterbatasan dalam penelitian ini masih kurang dalam tahun sampel perusahaan yang diteliti sehingga untuk peneliti selanjutnya diharapkan untuk menambah tahun sampel mungkin sampai 10 tahun atau lebih, agar mendapatkan hasil yang positif signifikan pada implementasi ERP terhadap nilai perusahaan.

\subsection{Saran}

Saran untuk peneliti selanjutnya yang ingin membahas tentang ERP mungkin dapat menambah variabel lain yang dipengaruhi oleh implementasi ERP sehingga adanya hal baru dalam penelitian selanjutnya dan menjadi tambahan ilmu bagi peneliti dan juga pembacanya.

\section{DAFTAR PUSTAKA}

Budi, E.S., \&Eka, N.R. (2014). AnalisisPengaruh Return On Equity, Debt To Equity, Growth, dan Firm Size Terhadap Price to Book Value pada Perusahaan Property dan Real Estate di Bursa Efek Indonesia. Jurnal Ekonomi, Manajemen dan akuntansi. 22(1) : 1-60.

Davenport, T. (1998). Putting The Enterprise Into The Enterprise System. Harvard Business Review.76(4):121-131.

Dityawarman et, al. (2016). Pengaruh Task-ERP Fit dan Pemanfaatan ERP Terhadap Kinerja Karyawan.Jurnal Administrasi Bisnis. 35(2):104-113.

Forslund, H. (2010). ERP Systems' Capabilities for Supply Chain Performance Management.Industrial Management dan Data Systems.110(3) : 351-367.

Hall, J.A. (2007). Accounting Information System, 4 th ed. Jakarta : Salemba Empat.

Hasnawati, S. (2005). Dampak Set Peluang Investasi Terhadap Nilai Perusahaan Publik di Bursa Efek Jakarta.Jurnal Akuntansi dan Auditing Indonesia. 9(2): 117-126.

Hunton, J.E., Lippincott, B.,\&Reck, J.L.(2002). Enterprise Resource Planning System: Comparing Firms Performance of Adopters and Nonadopters. International Journal of Accounting Information System. 04: 165-184.

Mabert et, al. (2000). Enterprise Resource Planning Survey of U.S Manufacturing Firms.Production and Inventory Management Journal.41(2) : 52-58.

Morris, J. (2011). The Impact Of Enterprise Resource Planning (ERP) System on the Effectiveness of Internal Control over Financial Reporting.Journal of Information System: Spring. 25(1):129-157. 
Nordin, Norani., \&Adegoke, O. (2015).Learning from ERP Implementation: A Case Study of Issues and Challenges in Technology Management. Jurnal Teknologi UTM. 74(1):57-62.

Poston, R. \&Severin, G. (2001).Financial Impact of Enterprise Resource Planning Implementations. International Journal of Information System. 2(4) : 271-294.

Rahmawati. (2008). Analisis Faktor-Faktor yang Berpengaruh Terhadap Pemanfaatan Teknologi Informasi.Jurnal Ekonomi dan Pendidikan. 5(1) : 107-118.

Sehwan et, al. (2016). Revisiting The Relationship Between Information Technology Capability and Firms Performance : Focusing on the Impact Of The Adoption of Enterprise Resource Planning System. The Journal of Information System. The Korea Assosiation of Information System. 25(1) : 49-73.

Susanti, R. (2010). Analisis Faktor-Faktor yang Berpengaruh Terhadap Nilai Perusahaan. Skripsi: Manajemen Keuangan. FE. Universitas Diponegoro.

Susanto, A. (2013). Impelementasi Sistem ERP (Enterprise Resources Planning) PT Pos Indonesia : Sebuah Inisiasi dan Strategi. Pusatlitbang Penyelenggara Pos dan Informatika-Kementrian Kominfo Jalan Medan Merdeka Barat No.9.

Syafira, N., Tohir, \& Suwarno. (2014). Pengaruh Mekanisme Corporate Governance, Leverage, Dan Profitabilitas Terhadap Nilai Perusahaan.Performanse.19(1) : 98111.

Tarigan, R. (2004). Perencanaan Pembangunan Wilayah. Jakarta: PT. Bumi Aksara.

Thavikulwat, P. (2004). Determining The Value of a Firm. Developments in Business Simulation and Experiantial Learning. 31 (Nomor) : 210-215.

Utami, S.S., Susilo, H., \&Riyadi. (2016). Analisis Penerepan Enterprise Resource Planning (ERP) (Studi pada PT Domusindo Perdana). Jurnal Administrasi Bisnis. 33(1):165.

Venkatraman, N. (1999). The Concept of Fit in Strategy Research: Toward Verbal and Statistical Correspondence. Academy of Management Review. 14(3): 423-444.

Welley, M. \&Victoria, U. (2015). Faktor-Faktor yang Mempengaruhi Nilai Perusahaan di Sektor Pertanian Pada Bursa Efek Indonesia Tahun 2010-2013.Jurnal EMBA. 3(1): 972-983.

Wibisono, S. (2005). Enterprise Resource Planning (ERP), Solusi Sistem Terintegrasi.Jurnal Teknologi Informasi DINAMIK.10(3): 150-159.

Wicaksono et, al. (2015). Analisis Dampak Penerapan Sistem ERP terhadap Kinerja Pengguna.Binus Business Review.6(1): 25-34.

Wijaya \&Suparto. (2009). Enterprise Resource Planning \& Solusi Bisnis. Yogyakarta : Graha Ilmu.

Yulianti \& Handayani P,W. (2011). Analisis Faktor-Faktor yang Mempengaruhi Penerimaan Pengguna dalam Menggunakan Sistem ERP.Journal of Information System.7(1) : 69-75. 